\title{
Mosquito Nest Eradication Behavior (PSN) in Communities in Rawabuntu Region South Tangerang
}

\author{
${ }^{1}$ Triana Srisantyorini, ${ }^{2}$ Pritha Erika Fiharshi, ${ }^{3}$ Nur Romdhona, ${ }^{4}$ Ernyasih \\ ${ }^{1-4}$ Faculty of Public Health, Muhammadiyah University of Jakarta \\ K.H. Ahmad Dahlan Street, Cireundeu, Ciputat, South Jakarta, 15419 \\ Email: trianasrisantyorini@yahoo.co.id
}

\begin{abstract}
Dengue Hemorrhagic Fever (DHF) is a disease that always increases and spreads widely. South Tangerang City is the highest city with several 417 cases in 2019. The role of the community is needed to break the chain of transmission using vector control through Mosquito Nest Eradication (PSN) activities. Activities such as eradicating mosquito eggs and larvae using $3 M$ plus. This study was conducted to determine the factors related to the behavior of Mosquito Nest Eradication (PSN) in the Community in the Rawabuntu. The method of research is quantitative analytic with a crosssectional design, univariate and bivariate analysis, primary data collection by filling out questionnaires using the PPS technique, and then by purposive sampling with an amount of 150 respondents. The result of the chi-square research shows that there is no correlation between knowledge and PSN behavior with a p-value $(0,132)$, there is no correlation between attitudes and PSN behavior with a p-value $(0,757)$, there is a correlation between information availability and PSN behavior with a p-value (0,001), there is a correlation between the role of health workers with PSN behavior with p-value $(0,011)$. The result of this study there is no correlation between knowledge and attitudes with PSN behavior, but there is a correlation between the availability of information and the role of health workers with behavior (PSN). It is expected that health workers will provide information and monitor community activities to carry out PSN activities and for the community to make efforts to increase knowledge and attitude regarding $P S N$ by conducting $3 M$ plus regularly to prevent dengue fever.
\end{abstract}

Keywords: Mosquito Nest Eradication, Behavior, Community 


\section{PENDAHULUAN}

Dengue hemorrhagic fever (DBD) is caused by infection with the den-1, den-2, den-3, or den4 virus transmitted by the bite of the Aedes aegypti and Aedes albopictus mosquitoes that are from other dengue sufferers. The four types of viruses have been found in various regions in Indonesia and the most are type 2 and type 3 (Rojali \& Amalia, 2020).

The transmission and spread of this disease are very fast and can cause an extraordinary outbreak, causing a lot of pain even to death so that the disease can cause panic in the community (Hidayat \& Nasriah, 2017).

Symptoms of this disease are usually characterized by sudden fever, headache, nausea, and manifestations of bleeding such as nosebleeds or bleeding gums as well as the presence of redness on the surface of the patient's body (Kemenkes RI, 2018).

According to the World Health Organization (2019), the problem of DENGUE has increased drastically around the world in recent decades. It is estimated that more than 3.9 billion people (more than $40 \%$ of the world's population) are at risk of dengue infection (WHO, 2019).

Dengue hemorrhagic fever cases reported in Indonesia in 2019 were recorded as many as 138,127 cases. Deaths caused by DENGUE disease in 2019 also increased compared to 2018, from 467 to 919 deaths (Kemenkes RI, 2019).

Dengue Hemorrhagic Fever (DBD) is a serious case in Banten Province, proven 8 districts/cities have been affected by dengue hemorrhagic fever. The incidence rate of DENGUD in Banten Province in 2019 was 16.6 per 100 (Dinkes Banten, 2020).

South Tangerang city also still occupies the highest disease in 2019 with the number of problems 417. Dengue Hemorrhagic Fever(DBD) in the Working Area of UPT Puskesmas Rawabuntu the number of dengue cases in 2019 in 33 cases, the number of problems in 2020 in 62 cases, and the number of cases in 2021 in 17 cases (PKM Rawabuntu, 2021).

Influencing factors in the incidence of Dengue Hemorrhagic Fever (DENGUE) disease in Indonesia are believed to be humans(hosts), dengue virus (agent), mosquitoes (vector), and environment(environment). Environmental factors such as geographical conditions (height of sea level, rainfall, rain, and humidity) demographic conditions (population density, population mobility, community behavior, customs, socioeconomic population, type and density of mosquitoes as vectors of disease transmission

Poor community behavior such as aspects of clean water reservoirs, landfills, container types, and habits in holding clothes are also very influential on the incidence of Dengue Hemorrhagic Fever (Fauji \& Al Banjary, 2020).

Control in the incidence of dengue hemorrhagic fever (DBD) is quite complex because there has been no cure for this disease (Hidayat \& Nasriah, 2017). The role of the community is needed in 
the prevention of Dengue Hemorrhagic Fever disease to break the chain of transmission using vector control through mosquito nest eradication (PSN) activities (Nurkhasanah et al., 2021).

Mosquito Nest Eradication Activities (PSN) are eradicating eggs and mosquitoes using 3M plus (Drain, Closing, and Burying) plus sowing larvacides, keeping fish in water shelters, and activities that can eradicate breeding Aedes mosquitoes (Kemenkes RI, 2011).

Factors that can influence mosquito nest eradication activities (PSN) by green behavior theory in Notoatmodjo (2014) are influenced by predisposing factors ( predisposing factor), supporting factors(enabling factor), and driving factors(reinforcing factor).

Success in dengue fever (PSN DBD) is influenced by various factors including knowledge, attitudes, actions, and sociodemographic characteristics such as age, marital status, education level, and employment status that can affect success in the implementation of dengue mosquito nest eradication in an area (Wong et al., 2015).

In connection with previous research, this obtained a value of $p<0.0001$. The $p$-value $<0.05$ indicates that there is a significant relationship between DBD and PSN knowledge to PSN behavior. In previous research related to attitudes by Listyorini (2016) Chi-Square test results obtained results $\mathrm{p}$ $=0.0001$ because the value of $\mathrm{p}(0.0001)$ is less than the value of $\alpha(0.5)$, it can be concluded that there is a significant relationship between attitude and behavior.

In previous research related to the availability of information by Nuryanti et al (2011) ChiSquare test results obtained results that $\mathrm{p}=0.0001$ which means that $p<0.05$ then Ha received or there is a significant relationship between the availability of information with mosquito nest eradication behavior and the results of variable Role of Health Workers obtained results that $\mathrm{p}=$ 0.0001 which means that $p<0.05$ then $\mathrm{Ha}$ is accepted or there is a significant relationship between the role of health workers and the behavior of eradicating dengue hemorrhagic mosquito nests in Karangjati Village.

Until now dengue hemorrhagic fever is still one of the problems that must be resolved immediately because it can affect adults and children. Control to break the chain of the spread of this disease must carry out Mosquito Nest Eradication Behavior (PSN) in the community.

Based on the above description, researchers are interested in knowing the factors related to mosquito nest eradication (PSN) behavior in communities in the RW 002 Rawabuntu Region in 2021.

\section{METHODS}

This type of research uses quantitative analytical surveys with cross-sectional analysis of univariate and bivariate analyses conducted to find out factors related to mosquito nest eradication (PSN) behavior in communities in the Rawabuntu region, South Tangerang. 
A cross-sectional study design is a study design that is used to find out public health problems to find out the prevalence of certain diseases in one area and to see the relationship of causation that undergoes permanent changes. (Budiarto \& Anggeraeni, 2001) The location of this study was conducted in RW 002 Rawabuntu Village, Serpong Subdistrict, South Tangerang City.

\section{RESULTS AND DISCUSSIONS}

The univariate analysis of respondents' characteristics describes the frequency distribution and descriptive statistics displayed with the shape of the frequency distribution table to find out the characteristics, age, gender, education, and employment in the RW 002 Rawabuntu region are as follows:

Table 1. Attributing respondents based on Age to the Community in Rawabuntu Region

\begin{tabular}{ccc}
\hline Age & $\mathbf{N}$ & \% \\
\hline $17-25$ & 34 & 22,7 \\
$26-35$ & 52 & 34,7 \\
$36-45$ & 40 & 26,7 \\
$46-55$ & 22 & 14,7 \\
$56-65$ & 2 & 1,3 \\
\hline Total & 150 & 100 \\
\hline
\end{tabular}

Based on Table 1 it is known that most respondents have the age of 26-35 years as many as 52 (34.7\%) compared to those aged 36-45 years as $40(26.7 \%)$, ages $17-25$ years as many as 34 $(22,7 \%)$, ages 46 - 55 years as many as $22(14,7 \%)$ and ages $56-65$ years as many as $2(1,3 \%)$.

Table 2. Attributing respondents based on Gender to The Community in Rawabuntu Region

\begin{tabular}{ccc}
\hline Gender & $\mathbf{N}$ & $\mathbf{\%}$ \\
\hline Man & 47 & 31,3 \\
Women & 103 & 68,7 \\
\hline Total & 150 & 100 \\
\hline
\end{tabular}

Based on Table 2 it is known that the most respondents are $103(68.7 \%)$ than men as many as $47(31,3 \%)$.

Tabel 3. Attributing Respondents based on Education to the Community in Rawabuntu Region

\begin{tabular}{ccc}
\hline Education & $\mathbf{N}$ & $\mathbf{\%}$ \\
\hline Elementary School & 7 & 4,7 \\
Junior High School & 14 & 9,3 \\
Senior High School & 71 & 47,3 \\
College & 58 & 38,7 \\
\hline Total & 150 & 100 \\
\hline
\end{tabular}

Based on Table 3, it is known that the most respondents have high school education as many as $71(47.3 \%)$ compared to Academic / College as 58 (38,7\%), junior high school 14 (9.3\%)and 
elementary school $7(4,7 \%)$.

Table 4. Attributing Respondents based on Work to the Community in Rawabuntu Region

\begin{tabular}{ccc}
\hline Job & $\mathbf{N}$ & \% \\
\hline Student & 14 & 9,3 \\
Private Employees & 48 & 32 \\
Civil Servants & 12 & 8 \\
Self employed & 27 & 18 \\
Housewife & 47 & 31,3 \\
Other & 2 & 1,3 \\
\hline Total & 150 & 100 \\
\hline
\end{tabular}

Based on Table 4, respondents have the most work as Private Employees as many as 48 (32\%) compared to Housewives as many as 47 (31.3\%), Self-employed as 27 (18\%), Students/ Students as many as $14(9.3 \%)$, civil servants as many as $12(8 \%)$ and others as educators $2(1.3 \%)$.

Table 5. Attributable respondents based on knowledge related to PSN to the community in Rawabuntu Region

\begin{tabular}{ccc}
\hline Knowledge & $\mathbf{N}$ & $\boldsymbol{\%}$ \\
\hline Less good & 66 & 44 \\
Good & 84 & 56 \\
\hline Total & 150 & 100 \\
\hline
\end{tabular}

Based on table 5 above, the frequency distribution for Knowledge related to Mosquito Nest Eradication Behavior (PSN) in the Community showed that 84 respondents (56\%) had good knowledge and 66 respondents $(44 \%)$ had poor knowledge.

Table 6. Attributing Respondents based on attitudes related to PSN to the community in Rawabuntu Region

\begin{tabular}{ccc}
\hline Attitude & $\mathbf{N}$ & $\mathbf{\%}$ \\
\hline Negative & 76 & 50,7 \\
Positive & 74 & 49,3 \\
\hline Total & 150 & 100 \\
\hline
\end{tabular}

Based on Table 6, the frequency distribution for attitudes related to Mosquito Nest Eradication Behavior (PSN) in the Community showed that 76 respondents $(50.7 \%)$ had a negative attitude and 74 respondents $(49.3 \%)$ had a positive attitude.

Table 7. Attributing Respondents based on the Availability of Infromasi related to PSN to the Community in Rawabuntu Region

\begin{tabular}{ccc}
\hline $\begin{array}{c}\text { Availability of } \\
\text { Information }\end{array}$ & $\mathbf{N}$ & $\mathbf{\%}$ \\
\hline Less good & 44 & 29,3
\end{tabular}




\begin{tabular}{ccc} 
Good & 106 & 70,7 \\
\hline Total & 150 & 100 \\
\hline
\end{tabular}

Based on table 7, it was found that the frequency distribution for The Availability of Infromationrelated to Mosquito Nest Eradication Behavior (PSN) in the Community showed that as many as 106 respondents $(70,7 \%)$ had good information availability and 44 respondents $(29,3 \%)$ had poor availability of information.

Table 8. Attributing Respondents Based on the Role of Health Officers related to PSN in the Community in Rawabuntu Region

\begin{tabular}{ccc}
\hline Role of Health Officer & $\mathbf{N}$ & \% \\
\hline Less good & 34 & 22,7 \\
Good & 116 & 77,3 \\
\hline Total & 150 & 100 \\
\hline
\end{tabular}

Based on table 8, it was found that the frequency distribution for the Role of Health Workers related to Mosquito Nest Eradication Behavior (PSN) in the Community showed that 116 respondents (77.3\%) had a Good Health Officer Role and 34 respondents (22.7\%) had a less good Officer Role.

Table 9. Attributing Respondents Based on PSN Behavior to The Community in Rawabuntu Region

\begin{tabular}{ccc}
\hline Behavior & $\mathbf{N}$ & $\mathbf{\%}$ \\
\hline Less good & 66 & 44 \\
Good & 84 & 56 \\
\hline Total & 150 & 100 \\
\hline
\end{tabular}

Based on table 9, the frequency distribution for Mosquito Nest Eradication Behavior (PSN) in the Community showed that 84 respondents (56\%) had good behavior and 66 respondents (44\%) had bad behavior.

Bivariate analysis is conducted by testing independent and dependent variables using the ChiSquare Test with a meaningful rate of $5 \%(p$-value $=0.05)$ and a degree of the meaning of $95 \%$ to determine the difference in proportion or percentage and the relationship between independent and dependent variables.

Table 11. Recapitulation of Bivariate Analysis Results

\begin{tabular}{|c|c|c|c|c|c|c|c|c|}
\hline \multicolumn{9}{|c|}{ Perilaku Pemberantasan Sarang Nyamuk } \\
\hline \multirow[t]{2}{*}{ Variabel } & \multicolumn{2}{|c|}{ Kurang Baik } & \multicolumn{2}{|c|}{ Baik } & \multicolumn{2}{|c|}{ Total } & \multirow{2}{*}{$\begin{array}{l}P \text { - } \\
\text { Value }\end{array}$} & \multirow{2}{*}{$\begin{array}{l}\text { OR }(95 \% \\
\text { CI })\end{array}$} \\
\hline & $\mathbf{N}$ & $\%$ & $\mathbf{N}$ & $\%$ & $\mathbf{N}$ & $\%$ & & \\
\hline \multicolumn{9}{|l|}{ Pengetahuan } \\
\hline Kurang Baik & 24 & 36,4 & 42 & 63,6 & 66 & 100 & 0,132 & 0,571 \\
\hline Baik & 42 & 50 & 42 & 50 & 84 & 100 & & $\begin{array}{l}(0,296- \\
1,105)\end{array}$ \\
\hline \multicolumn{9}{|l|}{ Sikap } \\
\hline Negatif & 32 & 42,1 & 44 & 57,9 & 76 & 100 & 0,757 & 0,856 \\
\hline
\end{tabular}




\begin{tabular}{|c|c|c|c|c|c|c|c|c|}
\hline \multicolumn{9}{|c|}{ Perilaku Pemberantasan Sarang Nyamuk } \\
\hline \multirow{2}{*}{$\begin{array}{l}\text { Variabel } \\
\text { Positif }\end{array}$} & \multicolumn{2}{|c|}{ Kurang Baik } & \multicolumn{2}{|c|}{ Baik } & \multicolumn{2}{|c|}{ Total } & \multirow[t]{2}{*}{$\mathbf{P}$ - } & \multirow{2}{*}{$\begin{array}{c}\text { OR }(\mathbf{9 5} \% \\
(0,449- \\
1,631)\end{array}$} \\
\hline & 34 & 45,9 & 40 & 54,1 & 74 & 100 & & \\
\hline \multicolumn{9}{|c|}{ Ketersediaan Informasi } \\
\hline Kurang Baik & 10 & 22,7 & 34 & 77,3 & 44 & 100 & \multirow[t]{2}{*}{0,001} & 0,263 \\
\hline Baik & 56 & 52,8 & 50 & 47,2 & 106 & 100 & & $\begin{array}{l}(0,118- \\
0,585)\end{array}$ \\
\hline \multicolumn{9}{|c|}{ Peran Petugas Kesehatan } \\
\hline Kurang Baik & 8 & 23,5 & 26 & 76,5 & 34 & 100 & \multirow[t]{2}{*}{0,011} & 0,308 \\
\hline Baik & 58 & 50 & 58 & 50 & 116 & 100 & & $\begin{array}{l}(0,129- \\
0,736)\end{array}$ \\
\hline
\end{tabular}

Based on Table 11, respondents who have good knowledge and behave well are 50\% lower than respondents who have less good knowledge but behave well, which is 63.6\%. Chi-Square statistical test results obtained a p-value by looking at Continuity Correction of 0.132 so that it can be concluded that there is no meaningful relationship between Knowledge and Mosquito Nest Eradication Behavior (PSN) in Communities in Rawabuntu Region.

The results of the analysis of respondents who have a positive attitude and behave well are $54.1 \%$ lower than respondents who have a negative attitude but behave well, which is $57.9 \%$. ChiSquare statistical test results obtained a p-value by looking at Continuity Correction of 0.757 so that it can be concluded that there is no meaningful relationship between Attitudes and Mosquito Nest Eradication Behavior (PSN) in Communities in Rawabuntu Region.

The results of the analysis of respondents who have the Availability of Good And WellBehaved Infromasi are $47.2 \%$ lower than respondents who have less well-being availability of information but are well behaved at $77.3 \%$. Chi-Square statistical test results obtained a $p$-value by looking at Continuity Correction of 0.001 so that it can be concluded that there is a meaningful relationship between the availability of information and mosquito nest eradication behavior (PSN) in communities in the rawabuntu region.

The bivariate analysis also obtained an odds ratio value of 0.263 with $\mathrm{CI}=0.118-0.585$, so it can be interpreted that respondents with poor information availability have a 0.263 times greater chance of having a less good Mosquito Nest Eradication Behavior (PSN) compared to respondents with the availability of good information.

The results of the analysis of respondents who have the role of health workers and behave well are 50\% lower than respondents who have a less good but well-behaved health worker role of 76.5\%. Chi-Square statistical test results obtained a $p$-value by looking at Continuity Correction of 0.011 so that it can be concluded that there is a meaningful relationship between the role of health workers and Mosquito Nest Eradication Behavior (PSN) in communities in the Rawabuntu Region.

The bivariate analysis also obtained an odds ratio of 0.308 with $\mathrm{CI}=0.129-0.736$, so it can be interpreted that respondents with a less good Health Officer Role have a 0.308 times greater 
chance of having a less good Mosquito Nest Eradication Behavior (PSN) compared to respondents with the Role of Good Health Officers.

This bivariate study shows that the amount of good knowledge is $50 \%$ while the knowledge is less good, which is $63.6 \%$. From the results of bivariate analysis using the Chi-Square Test obtained $p$-value $=0.132$ which means that knowledge has no relationship with Mosquito Nest Eradication Behavior (PSN) in Communities in the Rawabuntu Region.

This study is in line with the study of Taniansyah et al (2020) by showing a value of $\rho$-value of 0.138 which can be concluded that there is no relationship between knowledge and mosquito nest eradication behavior.

This study contradicts Wulandari's research (2013) the results of the analysis with chi-square test found a relationship $(\mathrm{p}<0.05)$ between respondents' knowledge and patient DBD behavior $(\mathrm{p}=$ 0.002). And this study is also not in line with Green's theory in Notoatmodjo (2014) which states that knowledge is a predisposing factor that gives rise to a person's behavior can be realized.

People who are less concerned about mosquito nest eradication (PSN) activities can cause poor behavior, therefore it is important to have good knowledge by looking for information related to PSN DBD to break the chain of dengue hemorrhagic fever transmission.

Hasil penelitian bivariat ini menunjukkan bahwa jumlah sikap positif yaitu sebesar 54,1\% sedangkan sikap negatif yaitu 57,9\%. Hasil analisis bivariat dengan menggunakan Uji Chi-Square di dapatkan $p$-value sebesar 0,757 yang berarti tidak ada hubungan yang signifikan antara sikap dengan Perilaku Pemberantasan Sarang Nyamuk (PSN) pada Masyarakat di Wilayah RW 002 Rawabuntu.

Penelitian ini sejalan dengan penelitian Gafur \& Jastam (2015) yang didapatkan hasil uji statistik Chi-Square diperoleh nilai $p=0,1000$ karena $p>a=0,05$ sehingga dapat disimpulkan tidak ada hubungan antara sikap dengan keberadaan jentik nyamuk.

Penelitian ini tidak sejalan dengan penelitian Puspitasari (2015) Hasil Uji Chi Square pada variabel sikap diperoleh nilai Continuity Corection sebesar 5,509 dan $p$-value 0,019<0,05, maka ada hubungan antara sikap dengan pemberantasan sarang nyamuk. Sikap berhubungan dengan motivasi individu atau kelompok pada saat melakukan sesuatu. Semakin baik sikap maka semakin baik pula tindakan yang dilakukan terhadap hal tersebut. Walaupun perilaku dipengaruhi oleh sikap, namun tidak selamanya akan terwujud dalam suatu tindakan. Perilaku akan terwujud jika ada dukungan lain yang mendorong seperti fasilitas, pengalaman, dan lain - lain (Taniansyah et al., 2020).

The results of bivariate analysis using the Chi-Square Test were obtained a p-value of 0.001 which means there is a significant relationship between the availability of Information and Mosquito Nest Eradication Behavior. This study is in line with Liestyana research (2019) which said that there is a relationship between the availability of information and mosquito nest eradication (PSN) behavior 
and having a $p$-value of $0.030(\mathrm{p}<0.05)$ which means there is a relationship between the availability of information and psn behavior.

Then strengthened by Nuryanti's research (2013) obtained the result that $\mathrm{p}=0.0001$ which means that $p<0.05$ then $\mathrm{Ha}$ is accepted or there is a significant relationship between the availability of information with the behavior of DENGUE hemorrhagic fever PSN in karangjati village This study is contrary to the research Widiyaning et al., (2018) The results of the analysis of the relationship showed $p$-value amounting to 0,136 , it can then be concluded that there is no relationship between the availability of information facilities and the practices of respondents in the prevention of DHF.

The availability of information is one of the contributing factors to the occurrence of a behavior. It is expected that with the availability of information, knowledge will increase and can also cause a positive attitude so that there will be changes in behavior. People who are less informed about dengue prevention are due to the distance of the house away from health care facilities, and the lack of home visits made by officers due to lack of health workers. (Syahrias, 2018) but with the help of media such as print media and the internet, the community can be helped so that it can lead to good behavior in carrying out the eradication of mosquito nets.

Bivariate results using Chi-Square have obtained a $p$-value of 0.011 so that means there is a significant relationship between the role of health workers and Mosquito Nest Eradication Behavior (PSN) in the Community in rw 002 Rawabuntu Region in 2021. This research is in line with Listyorini's research (2016) and the p-value of 0.0001 is smaller than the value of $\alpha(0.05)$, it can be concluded that there is a significant relationship between the role of health workers and psn dbd behavior.

This study is not in line with the Liestyana study (2019) Based on the results of the Chisquare test obtained a value of p-value (0.437) with $\alpha(0.05)$, so it is known that $\mathrm{p}$-value $>\alpha$, which means there is no relationship between the role of health workers and PSN behavior. T obtained pValue $=0.684(\mathrm{p}>0.05)$ means there is no relationship between the role of officers and PSN.

In the case of DBD from the government, there must be steps or contributions owned by health workers (be it physical, material, non-material). In addition, community leaders also play a role in the success of the prevention of DENGUD events because with the existence of community leaders who can increase awareness and guide the community so that there are no DBD events such as conducting counseling activities to the community assisted by cadres, such as providing larvacide in the form of abate, fogging. under certain conditions. In addition, it can also invite the public to check the presence of mosquitoes in bathtubs, water shelters (landfill), and puddles in the home environment (Putra, 2020). 
The role of health workers is very important because it can reinforce behavior changes and monitor a person's behavior. The role of health workers can motivate the community so that the community can provide good behavior in carrying out the eradication of mosquito nets.

\section{CONCLUSIONS AND SUGGESTIONS}

1. Knowledge of respondents related to Eradication of Mosquito Nests (PSN) As many as 84 respondents $(56 \%)$ have good knowledge.

2. Respondents' attitudes related to Mosquito Nest Eradication (PSN) As many as 76 respondents $(50.7 \%)$ had a negative attitude.

3. Availability of information related to the eradication of mosquito nests (PSN) as many as 106 respondents $(70.7 \%)$ have the availability of good information.

4. The role of health workers related to the eradication of mosquito nests (PSN) as many as 116 respondents $(77.3 \%)$ have the role of good health workers.

5. Respondent behavior related to Mosquito Nest Eradication (PSN) as many as 84 respondents (56\%) have good behavior.

6. There is no meaningful relationship between knowledge and Mosquito Nest Eradication Behavior (PSN) in Communities in Rawabuntu Region ( $p$-value $=0.132$ )

7. There is no meaningful relationship between Attitudes and Mosquito Nest Eradication Behavior (PSN) in Communities in Rawabuntu Region ( $p$-value $=0.757$ )

8. There is a meaningful relationship between the availability of information and mosquito nest eradication behavior (PSN) in communities in the rawabuntu region ( $p$-value $=0.001$ ).

9. There is a meaningful relationship between the role of health workers and Mosquito Nest Eradication Behavior (PSN) in Communities in the Rawabuntu Region ( $p$-value $=0.011$ )

\section{The advice on this study is}

\section{a. Puskesmas Rawabuntu}

For Puskesmas Rawabuntu, it is expected that health workers routinely provide information and monitor the public to perform mosquito nest eradication (PSN) to prevent dengue hemorrhagic fever disease.

b. For the people of Rawabuntu

The people of Rawabuntu are expected to make efforts to increase knowledge and attitudes related to the eradication of mosquito nests and carry out regular PSN activities such as doing 3Mplus to prevent dengue hemorrhagic fever.

c. For the Next Researcher 
Further researchers are expected to develop research and add other variables that have a relationship with Mosquito Nest Eradication (PSN).

\section{REFERENCES}

Apriyani, Umniyati, S. R., \& Sutomo, A. H. (2017). Environmental sanitation and the presence of Aedes sp flick with dengue hemorrhagic fever incidence in Banguntapan Bantul Environmental sanitation and the presence of larvae Aedes sp. with dengue hemorrhagic fever incidence in Banguntapan Bantul. Journal of Public Medicine News, 33,79-84.

Arsin, A. A. (2013). Epidemiology of DENGUE in Indonesia. 15-18.

Bakta, N. N. Y. K., \& Bakta, I.M. (2015). The Relationship Between Knowledge and Attitudes Towards Mosquito Nest Eradication Behavior (PSN) as a Prevention of Dengue Hemorrhagic Fever (DBD) in Banjar Badung, Melinggih Village, Payangan Health Center Area in 2014. EJurnal Medika Udayana, 4(6), 1-12.

Budiarto, E., \& Anggeraeni, D. (2001). Introduction to Epidemiology. Egc Medical Book.

Ministry of Health. (2004). Dengue Hemorrhagic Fever Management in Indonesia. In the Ministry of Health: Vol. keti edition (pp. 1-62). https://silahuddinm.files.wordpress.com/2013/02/bk2007g4.pdf

Ministry of Health. (2005). Prevention and Eradication of Dengue Hemorrhagic Fever in Indonesia. Directorate General of Disease Control and Environmental Health.

Dewi, N. P. (2015). Factors Related to the Practice of Eradicating Dengue Hemorrhagic Fever Mosquito Nest (PSN DBD) Families in Mulyoharjo Village Jepara District Jepara Regency. Lib Unnes, 1-73.

Dewi, N. P., \& Azam, M. (2017). Factors Related to Family PSN-DBD Practices in Mulyoharjo Village. Public Health Perspective Journal, 2(1), 80-88.

Dian Paramitha, N. K. (2018). Information Source Relationship With Participation of Women of Childbearing Age (WUS) Conducts Visual Inspection Examination of Acetic Acid (IVA). Thesis,6-9. http://repository.poltekkes-denpasar.ac.id/915/

Dinkes Banten. (2020). Health Profile of Banten Province. Sasmitodia,1-5.

Directorate of Health Promotion and Community Empowerment. (2019). Dbd Prevention Efforts with 3M Plus.https://promkes.kemkes.go.id/upaya-pencegahan-dbd-dengan-3m-plus

Director-General of Disease Control and Environmental Health. (2008). Training Module for Dengue Hemorrhagic Fever Mosquito Nest Eradication (PSN-DBD) Trainers with Communication For Behavioral Impact Approach.1-141.

Efruan, L. J., \& Sugiyanto, Z. (2015). Public Behavioral Relations (Knowledge, Attitudes, and Dbd Penular in the Working Area of Ngaliyan Health Center of Semarang City in 2015. Faculty of Health, Dian Nuswantoro University, 1-12.

Fauji, R. R., \& Al Banjary, M. A. (2020). THE WORKING AREA OF PUSKESMAS DIRGAHAYU KOTABARU REGENCY IN 2020 Islamic University of Kalimantan (Uniska). 1-8.

Gafur, A., \& Jastam, M. S. (2015). Factors Related to the Presence of Aedes aegypti MosquitoEs in Batua Village of Makassar City in 2015. Journal of Public HealthScience, 7(1), 50-62.

Hardani, H., Sukmana, D. J., Andriani, H., \& Fardani, R. (2020). Book qualitative \& quantitative research methods (Issue March).

Hastono, S. P. (2016). Data Analysis in the Field of Health. Rajawali Press.

Hidayat, \& Nasriah. (2017). Factors Related to dengue incidents in Balang Lapo Island pangkep 
regency. Journal of Sulolipu, 17(Supplement), S-102.

Hoetomo. (2005). Complete Dictionary Indonesian. Student Partners.

Kemenkes RI. (2011). Dengue Fever Control Module, Dengue Hemorrhagic Fever Epidemiology.

Kemenkes RI. (2016). Infodatin DBD situation in Indonesia. In dbd situation in Indonesia (pp. 1-12). Kemenkes RI. (2017). Indonesian Dengue Hemorrhagic Fever Guidelines.12-38.

Kemenkes RI. (2018). Dengue Fever Situation in Indonesia 2017. In The Journal of Vector Ecology
(Vol.
31 ,
Issue
1 ,
pp.
71-78).

https://www.kemkes.go.id/download.php?file=download/pusdatin/infodatin/InfoDatin-SituasiDemam-Berdarah-Dengue.pdf

Kemenkes RI. (2019). Indonesia Health Profile 2019. In the Ministry of Health Republic Indonesia (Vol. 42, Issue 4).

Ministry of Health. (2016). Technical Instructions for Implementation of PSN 3M-PLUS with Movement 1 House 1 Jumantik. Directorate General of Prevention and Control of Vector and ZoonoticDiseases.

KNEPK. (2011). National Guidelines for Health Research Ethics 2011. R\&D of the Ministry of Health, 1-134. http://www.ke.litbang.kemkes.go.id/kom14/wpcontent/uploads/2017/12/Pedoman-Nasional-Etik-Penelitian-Kesehatan-2011-UneditedVersion.pdf

Kurniawan, A. W., \& Puspitaningtyas, Z. (2016). Quantitative Research Methods. In Philosophy of Science (Vol. 4, Issue 4). Pandiva book. http://www.ncbi.nlm.nih.gov/pubmed/19528854\%0Ahttp://libproxy.unm.edu/login?url=http://se arch.ebscohost.com/login.aspx ?direct=true $\& d b=a 9 h \& A N=51827937 \&$ site $=$ eds-

live \&scope $=$ site $\% 5 \mathrm{Cnhttp}: / /$ content.ebscohost.com.libproxy.unm.edu/ContentServer.asp?T=P\& $\mathrm{P}=\mathrm{AN} \& \mathrm{~K}=51$

Liestyana, C. (2019). factors related to the behavior of PSN (Eradication of Mosquito Nests) in the community in the village of oro-oro ombo city of Madiun. Thesis,37. http://repository.stikesbhm.ac.id/569/1/1.pdf

Lim, H., Lindarto, D., \& Zein, U. (2014). Principles of Pharmacology-Endocrine-Infection. PT. Sofmedia.

Listyorini, P. I. (2016). Factors That Affect Mosquito Nest Eradication Behavior (PSN) in Karangjati Community blora regency. Journal INFOKES, 6(1), 6-15.

Mampuni, Y., \& Lestari, W. (2015). CEKAL (Prevent \& Tangkal) until the End of Dengue Fever. Rapha Publishing.

Monintja, T.C. N. (2015). The Relationship Between Individual Characteristics, Knowledge and Attitudes with the Actions of PSN DBD Malalayang Village Community I Malalayang District Manado City. Sam Ratulangi Manado University, 5,503-519.

Notoatmodjo, S. (1993). Health Research Methods. Rineka Cipta.

Notoatmodjo, S. (2003). Education and Behavioral Health. Rineka Cipta.

Notoatmodjo, S. (2011). Public Health Sciences and Arts. Rineka Cipta.

Notoatmodjo, S. (2014). Health Behavioral Sciences. Rineka Cipta.

Notoatmodjo, S. (2018). Health Research Methods. Rineka Cipta.

Nugraha, J. (2013). Introduction to Katagorik DataAnalysis. Deepublish.

Nurkhasanah, D. A., Sitorus, R. J., \& Listiono, H. (2021). Factors Associated with the Prevention of Dengue Hemorrhagic Fever (DBD). 21(1), 277-281. https://doi.org/10.33087/jiubj.v21i1.1164

Nursalam. (2003). Concept and Application of Nursing Science Research Methodology. Salemba 
Medika.

Nuryanti, E. (2013). Mosquito Nest Eradication Behavior in the Community. Journal of PublicHealth, 9(1), 15-23. https://doi.org/10.15294/kemas.v9i1.2825

Nuryanti, E., Bm, S., \& Cahyo, K. (2011). Mosquito Nest Eradication Behavior in Karangjati Village Community blora regency. Indonesian Journal of Health Promotion, 6(2), 130-139. https://doi.org/10.14710/jpki.6.2.130-139

PKM Rawabuntu. (2021). Data DBD Puskesmas Rawabuntu.

Puspitasari, N. E. (2015). The relationship between knowledge, attitude, and motivation with the eradication of mosquito nests in the village of kudu baki sukoharjo.

Son, D. A.M. (2020). The participation of health workers and community leaders in the containment of DBD incidents in Magetan Regency. Thesis, 5(1), 1-111.

Ratnawati, R. (2017). Factors related to the preventive behavior of dengue disease. Journal of Chemical Information and Modeling, 01(01), 1689-1699.

Rojali, R., \& Amalia, A. P. (2020). Community Behavior towards DBD Incidents in Ciracas District of East Jakarta. Manarang HealthJournal, 6(1), 37. https://doi.org/10.33490/jkm.v6i1.219

Saputro, P. A. (2017). The Role of The Jentik Monitoring Cadre (Jumantik) with Family behavior in Eradication of Mosquito Nests (PSN) Causes DENGUE. Occupational Medicine, 53(4), 130.

Sartiwi, W., Apriyeni, E., \& Sari, I. K. (2016). Knowledge and Attitude Relationship with Family Behavior on Eradication of Dengue-Bleeding Mosquito Nests. Journal of Health Medika Saintika, 9(2), 148-158. https://jurnal.syedzasaintika.ac.id

Soedarto. (2009). Infectious Diseases in Indonesia. Sagung Seto.

Soedarto. (2012). Dengue Hemorrhagic Fever. Sagung Seto.

Susmaneli, H., \& Darmita, L. (2018). Public Behavioral Relations in The Eradication of Aedes Mosquito Nests. 241-246.

Syahrias, L. (2018). Behavioral Factors of Dengue Hemorrhagic Fever Prevention (DBD) in Mangsang Village, Batam City. Journal of the World ofMas, 7,134-141.

Taniansyah, D. S., Widjanarko, B., \& Husodo, B. T. (2020). Factors Related to Mosquito Nest Eradication Behavior Kos Janitor In Tembalang Village. Journal of Public Health, DiponegoroUniversity, 8(September), 707-713.

Taqwa, I. (2015). Distribution of Frequency and Relationship of Knowledge, Attitudes, and Behavior of The Community with Efforts to Eradicate Dengue Hemorrhagic Fever Mosquito Nest (PSNDBD) in the Working Area of The Integrated City Health Center Of Rambutan Ogan ILir River in 2014.

Tsulasi, B. A. I. (2016). Knowledge Level Relationship with Dengue Prevention Behavior Through Dengue Hemorrhagic Mosquito Nest Eradication Program (PSN-DBD) in Raharja Village of Banjar City.

Waruwu, M. K., Sukartini, T., \& Indarwati, R. (2014). Knowledge and Motivation Relationship with Maternal Behavior in Mosquito Nest Eradication (PSN) DBD. Prodi Ners, 1(1), 43-51.

WHO. (2019). Establishing syndromic surveillance and event-based surveillance systems for Zika, dengue, and other arboviral diseases. In Control of Communicable Diseases Manual.https://doi.org/10.2105/ccdm.2745.022

Widiyaning, M. R., Syamsulhuda, B.M., \& Widjanarko, B. (2018). Factors Related to Dengue Hemorrhagic Fever Prevention (Dbd) Practice by Housewives in Doplang Village, Purworejo. Journal of Public Health (e-Journal), 6(1), 761-769.

Widoyono. (2008). Epidemiology, Transmission, Prevention \&ballast. Erlangga. 
Wong, L. P., Shakir, S.M.M., Atefi, N., \& AbuBakar, S. (2015). Factors affecting dengue prevention practices: Nationwide survey of the Malaysian public. PLoS ONE, 10(4), 1-16. https://doi.org/10.1371/journal.pone.0122890

Wulandari, U.M. (2013). Relationship of Characteristics and Knowledge of Mothers With PSN-DBD Behavior in Jawi Pontianak River Village in 2013. Integration of Climate Protection and Cultural Heritage: Aspects in Policy and Development Plans. Free and Hanseatic City of Hamburg, 26(4), 1-37. 